\title{
ANIMASI 3D TEKNIK-TEKNIK PENCAK SILAT BERBASIS ANDROID
}

\author{
Ryo Agung Waskita \\ Fakultas Teknik, Program Studi Teknik Informatika \\ Universitas Muria Kudus \\ Email: ryowaskita@gmail.com \\ Rina Fiati \\ Fakultas Teknik, Program Studi Teknik Informatika \\ Universitas Muria Kudus \\ Email: rina.fiati@umk.ac.id \\ Alif Catur Murti \\ Fakultas Teknik, Program Studi Teknik Informatika \\ Universitas Muria Kudus \\ Email: alif.catur@umk.ac.id
}

\begin{abstract}
ABSTRAK
Tujuan dari penelitian ini adalah untuk memberikan pembelajaran tentang teknik bela diri pencak silat berbasis multimedia dalam bentuk animasi. Dimana animasi ini terdapat teknik-teknik pencak silat yang didalamnya menggabungkan seperti elemen teks, gambar, visual audio dan video dan juga untuk memodernisasi pembelajaran pada animasi 3D tenik-teknik pencak silat supaya mengangkat minat oleh semua kalangan usia yang memiliki bakat dalam pencak silat. Metode yang digunakan dalam penelitian ini adalah metode Multimedia Development Life Cycle (MDLC) yang terdiri dari Concept, Design, Obtaining, Content Material, Assembly, Testing, dan Distribution, dan dibuat menggunakan perangkat lunak Blender, Adobe Flash, dan Camtasia studio. Animasi yang digunakan untuk kepentingan belajar sangat memberikan dampak positif perkembangan perangkat lunak multimedia yang tidak lagi dalam bentuk teks dan gambar saja, yang dapat diimplementasikan dengan cepat, tepat, dan akurat dan dapat digunakan sebagai sarana pembelajaran kebudayaaan Indonesia. Hasil dari penelitian ini dapat diimplementasikan dalam bentuk animasi media interaktif.
\end{abstract}

Kata kunci: animasi, multimedia, $M D L C$, teknik-teknik pencak silat.

\begin{abstract}
The purpose of this study is to provide learning about martial arts-based multimedia martial arts techniques in the form of animation. Where this animation there are techniques of martial arts in which combine text elements such as images, visual audio and video and also to modernize learning on 3D animation tenik-pencak silat techniques in order to raise interest by all age groups who have talent in martial arts. The method used in this research is Multimedia Development Life Cycle (MDLC) method which consists of Concept, Design, Obtaining, Content Material, Assembly, Testing, and Distribution, and created using Blender, Adobe Flash and Camtasia studio software. Animation used for the benefit of learning is very positive impact of the development of multimedia software that is no longer in the form of text and images only, which can be implemented quickly, precisely, and accurately and can be used as a means of learning Indonesian culture. The results of this research can be implemented in the form of interactive media animation.
\end{abstract}

Keywords: animation, multimedia, MDLC, teknik-teknik pencak silat.

\section{PENDAHULUAN}

Pencak silat merupakan salah satu olahraga beladiri yang terdapat di Indonesia. Pencak silat dapat dimainkan secara perorangan, berpasangan maupun beregu. Menguasai beladiri pencak silat sangat diperlukan penguasaan teknik dasar pencak silat. Mendengar tentang pencak silat orang awam pasti tertarik dengan salah satu cabang olahraga ini, karena pencak silat lahir dari kebudayaan bangsa Indonesia, maka perkembanganya lahir dari watak selera, dan bakat masyarakat yang ada di Indonesia selain itu keadaan masyarakat dan faktor alam juga dapat mempengaruhi perkembangan pencak silat itu sendiri[1]. 
Berbagai jenis pada penelitian sebelumnya telah dikembangkan media pembelajaran interaktif seperti "Rancangan Bangun Aplikasi Pembelajran Aksara Jawa Berbasis Android"[2]pada penelitian ini bertujuan untuk memberikan pembelajaran tentang aksara jawa dengan menggunakan media berbasis android. Penelitian yang telah dikembangkan media interaktif "Membangun Game Petualangan Sejarah Peninggalan Sunan Kudus Berbasis Android"[3]dengan menggunakan metode penelitian reserch dan development sebagai metode pembuatan game, tahapan dalam proses penelitian ini adalah tahap analisis, desain, pengembagan, implementasi, dan pengujian. Selain itu perkembangan dunia IT dalam bentuk animasi juga dapat diterapkan pada bidang psikotes dalam hal ini telah dikembangkan pada penelitian"Sistem Penentuan Bakat Dan Minat Anak Berbasis Mobile Android (Studi Kasus Siswa Kelas 4, 5, Dan 6 Sekolah Dasar)"'[4] Dengan adanya pembuatan aplikasi psikotes pada mobile Android dapat digunakan untuk mengetahui minat dan bakat yang dimiliki siswa sekolah dasar. Psikotes yang dilakukan meliputi subtes pengetahuan umum, antonim, bahasa Indonesia, bahasa Inggris, ilmu pengetahuan alam (IPA), ilmu pengetahuan sosial (IPS), tes gambar, matematika, dan tes mengingat. Maka dari itu sebagai riset pembanding peneliti membuat sebuah penelitian "Media Interaktif Animasi 3D Teknik-teknik Pencak silat berbasis Android"[5]yang nantinya diharapkan bisa mengangkat minat masyarakat luas untuk mengenal dan mempelajari kebudayaan pencak silat yang lahir dari nenek moyang bangsa Indonesia.

\section{METODOLOGI PENELITIAN}

Metodologi yang digunakan dalam pengembangan multimedia pada penelitian ini terdiri dari enam tahap, yaitu konsep (concept), perancangan (design), pengumpulan materi (material collecting), pembuatan (assembly), pengujian (testing), dan pendistribusian (distribution). Diagram metode pengembangan multimedia ditunjukkan pada gambar 1.

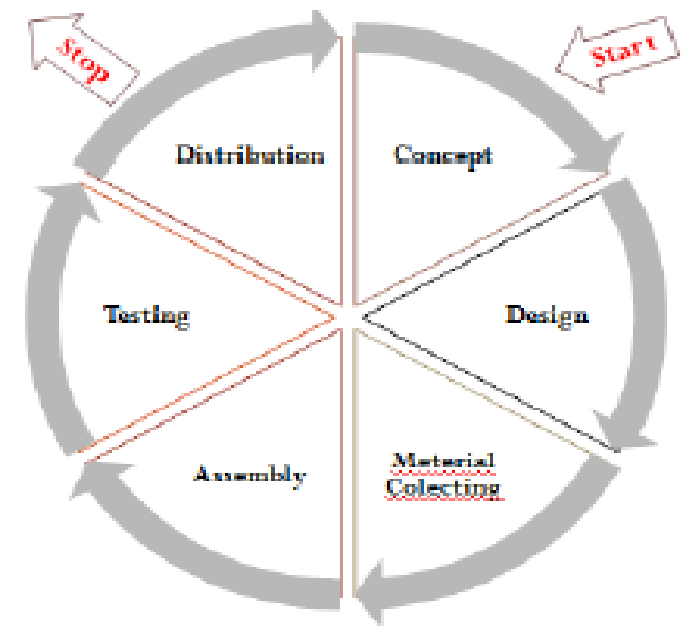

Gambar 1. Diagram Metode Pengembangan Multimedia [6]

\subsection{Algoritma Pengembangan Media Interaktif}

Tahapan perancangan Algoritma, pada tahap pembuatan algoritma ini peneliti mencoba untuk menjelaskan algoritma yang digunakan dalam pembuatan media interaktif ini dalam bentuk diagram alir algoritma yang ditunjukan pada gambar 2 . 


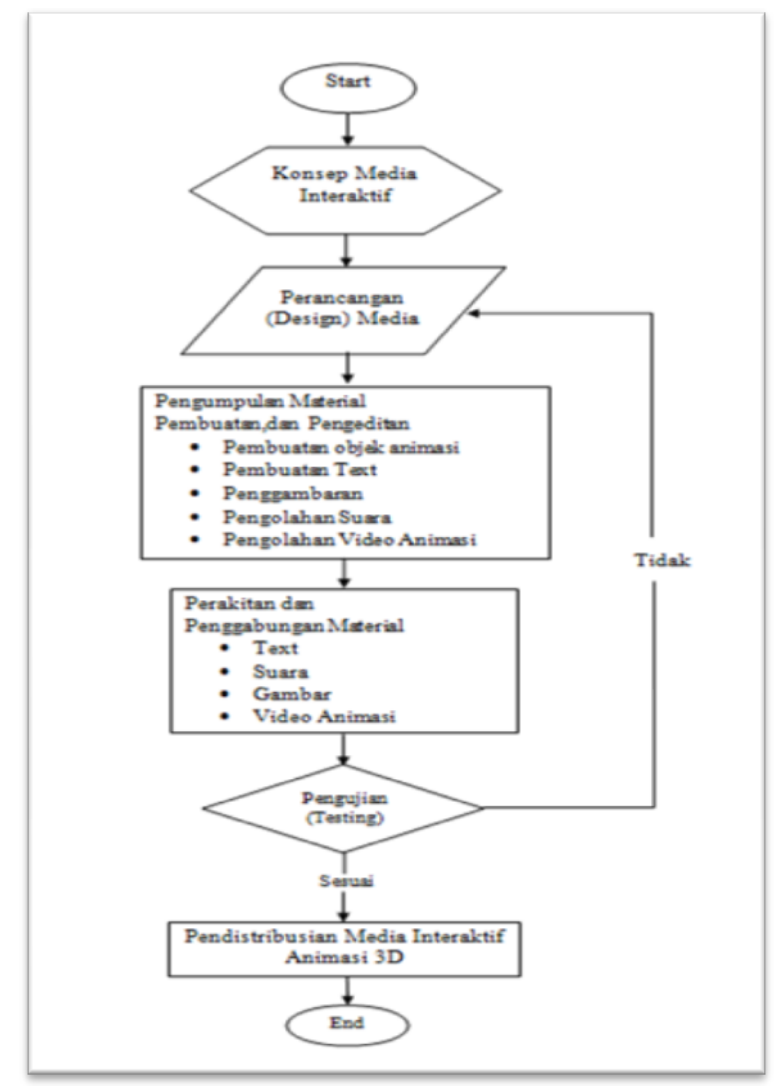

Gambar 2. Algoritma Pengembangan Media Interaktif

\subsection{Perancangan Storyboard}

Storyboard dibuat dalam beberapa sequence, tiap sequence ada keterangan cerita. Storyboard animasi 3D "Animasi 3D Teknik-Teknik Pencak silat" adalah sebagai berikut, yang ditunjukan pada gambar 3 .

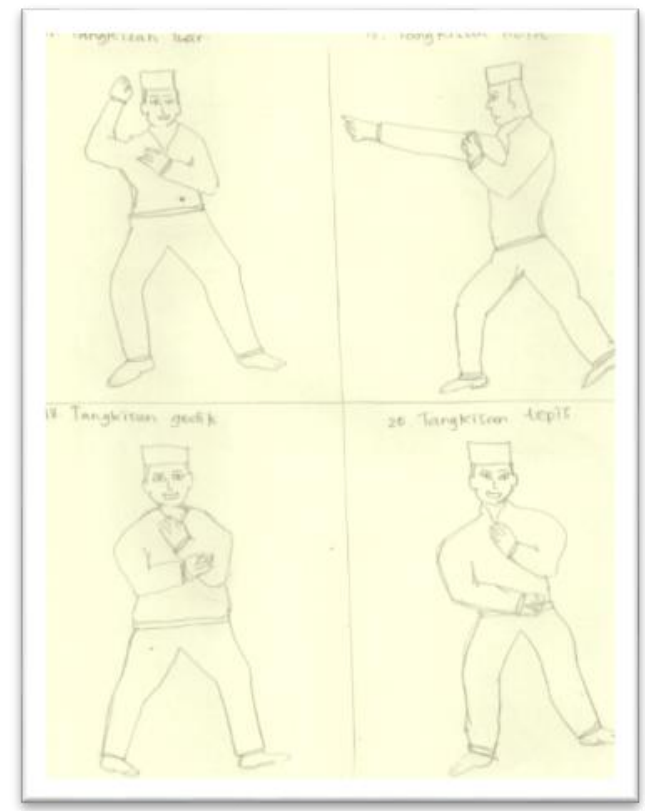

Gambar 3. Perancangan Storyboard 


\section{HASIL DAN PEMBAHASAN}

Tahap i mplementasi adalah tahap pengembangan dari tahap perancangan yang dibahas pada bab sebelumnya. Pada tahap ini merupakan tahap implementasi perancangan aplikasi ke dalam bentuk pembuatan aplikasi sesungguhnya serta pengujian aplikasi yang telah dibangun. Dalam tahap implementasi ini untuk membuat aplikasi harus didukung dengan tool yang sesuai spesifikasi yang dibutuhkan serta media visualisasi yang sesuai kebutuhan juga, karena aplikasi ini divisualisasikan melalui personal computer $(P C)$ berbasis extensi, maka dibutuhkan spesifikasi personal computer (PC) sesuai kebutuhan.

\subsection{Analisis Kebutuhan Software}

Analisis kebutuhan software yang dibutuhkan dalam pembuatan animasi ini adalah sebagai berikut:

a. Sistem Operasi Windows 7

b. Blender, sebuah aplikasi yang digunakan untuk mendesain dan membuat objek-objek 3D dan dapat digunakan juga sebagai alat untuk membuat video animasi.

c. Camtasia Studio, program software yang digunakan untuk mengedit video, membuat efek transisi, dan memasukkan nada intrumen dalam video.

d. Adobeflash, aplikasi yang digunakan untuk merangkai atau membangun aplikasi media animasi.

\subsection{Analisis Kebutuhan Hardware}

Kebutuhan hardware yang diperlukan dalam pembuatan animasi adalah sebagai berikut :

a. PC / Laptop Sistem Operasi Windows 64bit

b. Mouse

c. Keyboard

d. Sound

\subsection{Langkah Pembuatan Media Interaktif}

\subsubsection{Pembuatan Objek 3D}

Pembuatan objek animasi merupakan tahap pembuatan objek animasi yang menjadi objek dalam animasi teknik pencak silat. Objek animasi yang dibuat menggunakan aplikasi Blender. Pada tahap ini objek animasi yang dibuat proses setiap gerakan teknik-teknik pencak silat secara detail, tahap-tahap pembuatan objek animasi sebagai berikut :

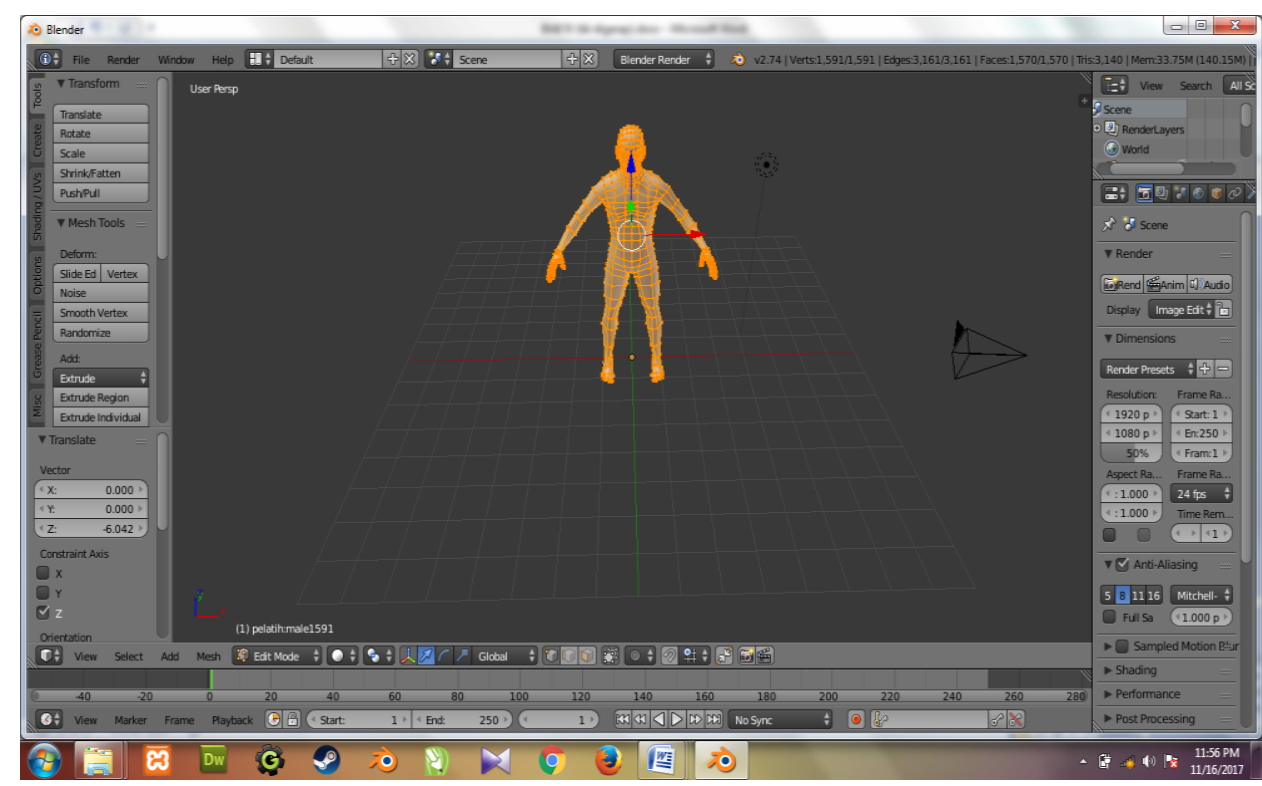

Gambar 4. Pembuatan Objek Animasi Pelatih Pencak Silat 


\subsubsection{Tahap Editing Video dan Pemberian Backsound}

Pada tahap ini adalah tahap membuat video animasi dari hasil video render objek animasi serta memberikan backsound berupa instrumen nada menggunakan aplikasi Camtasia Studio. Tahap pembuatan instumen sebagai berikut :

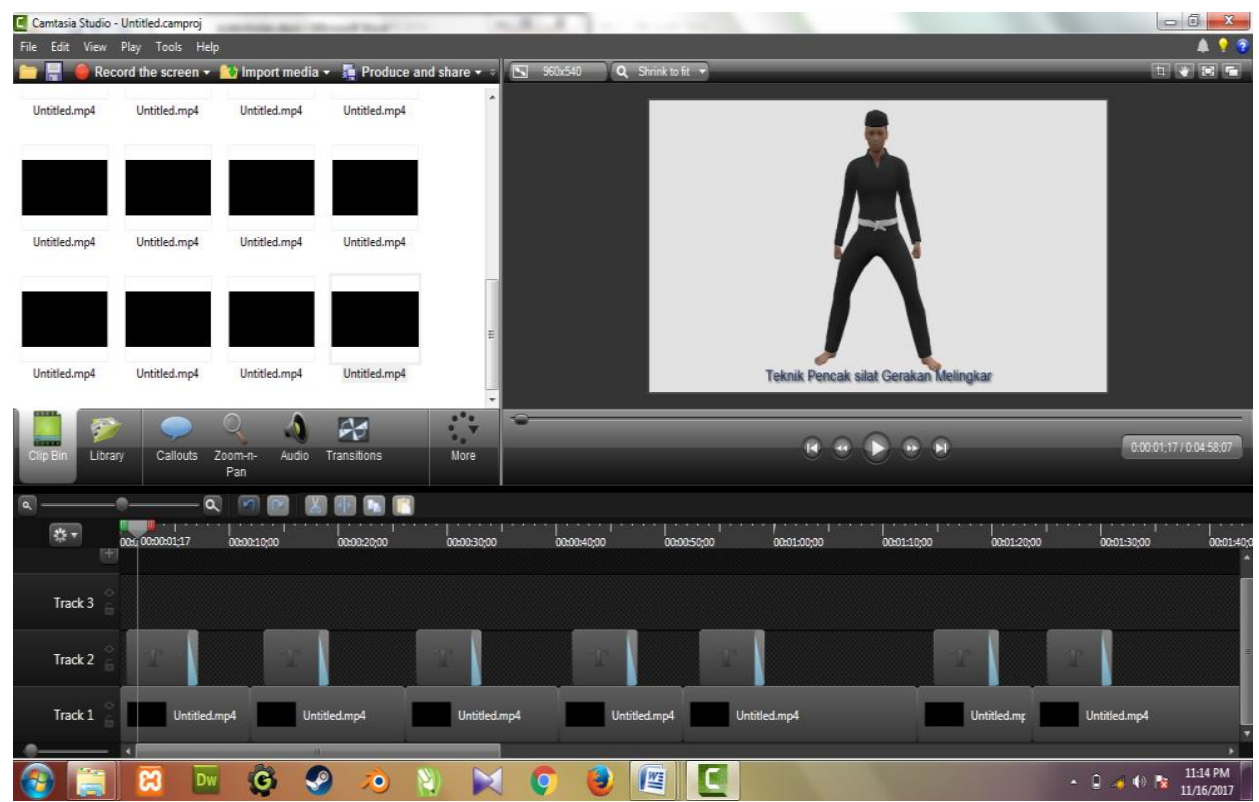

Gambar 5. Tahap Penambahan Narasi Dan Backsound

\subsubsection{Tahap Membuat Aplikasi (*.apk) pada Adobe Flash}

Adobe Flash Professional CCmenyediakan fasilitas kepada pengguna untuk membuat aplikasi berbasis dekstop dengan tools dan source code yang lumayan lengkap, tahap pembuatan aplikasi (*.apk) sebagai berikut :

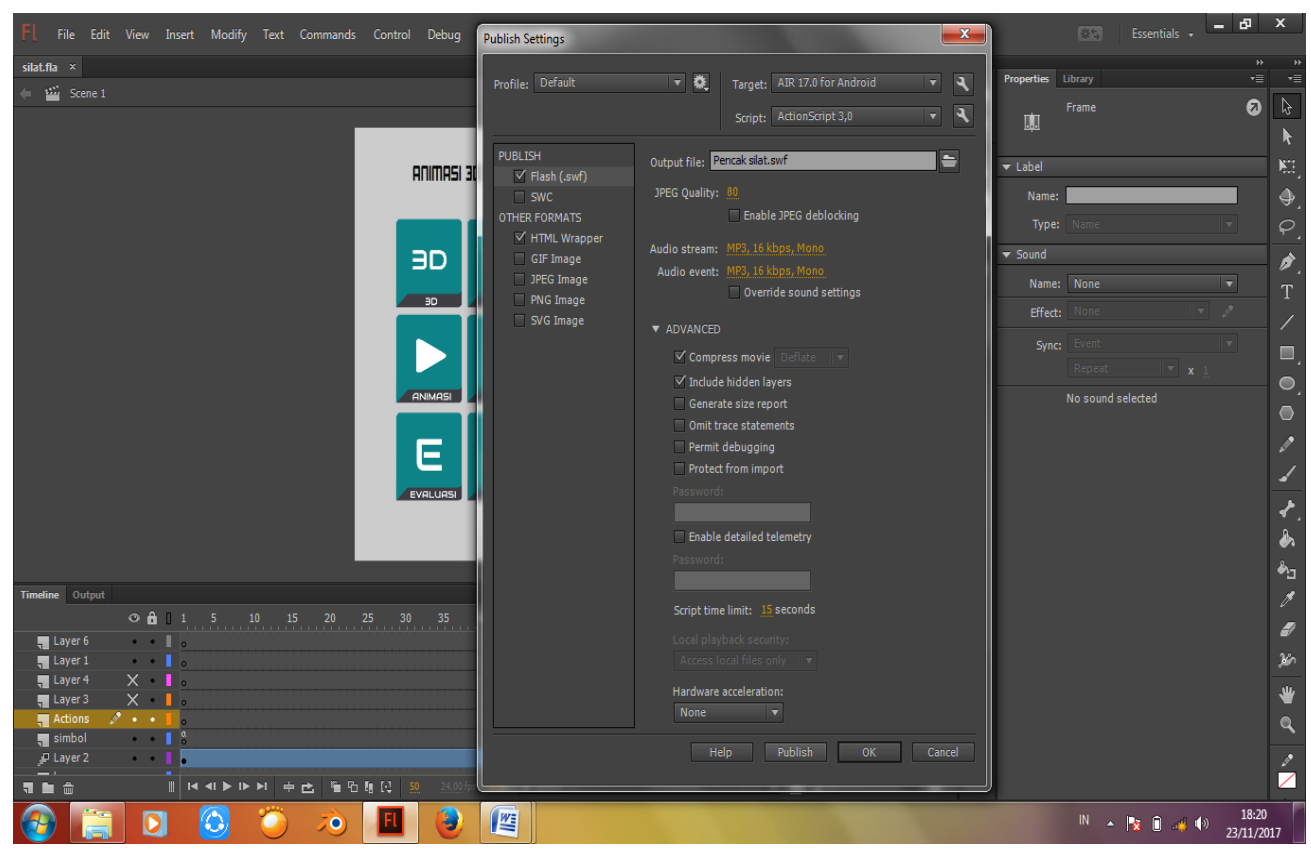

Gambar 6. Pembuatan Aplikasi (*.Apk) 


\subsubsection{Hasil Aplikasi}

Pada Gambar 7 meruapakan tampilan aplikasi setelah di install pada dekstop pada masing-masing halaman menu aplikasi. Pada halaman ini menampilkan layar pembuka dari aplikasi "Media Interaktif Animasi 3D Teknik-teknik pencak silat”. Dihalaman menu utama aplikasi terdapat 6 menu utama. Menu utama aplikasi adalah tentang 3D, animasi, evaluasi, galeri, profil, dan keluar. Tampilan menu utama aplikasi ditunjukkan pada gambar 7 .

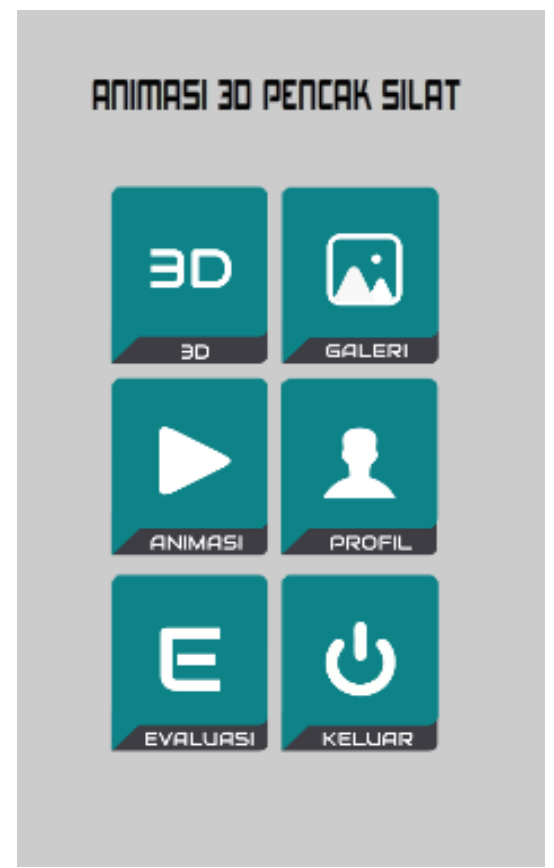

\section{Gambar 7. Tampilan Menu Utama}

a. Tampilan Isi Menu 3D

Isi dari menu 3D menampilkan gambar tentang sejarah pencak silat secara singkat. Isi menu 3D ditunjukkan pada gambar 8 .

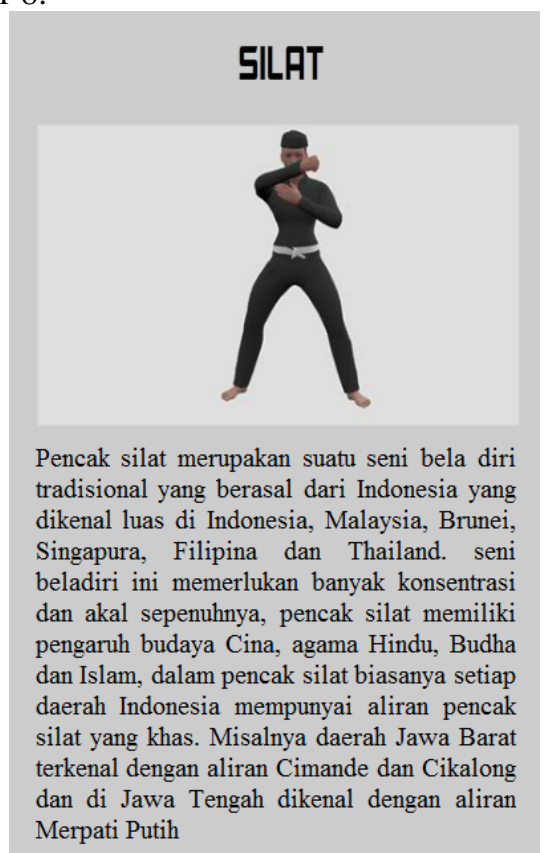

Gambar 8. Isi Menu 3D 
b. Tampilan Isi Menu Animasi

Pada menu animasi berisi tentanganimasi 3D gerakan teknik pencak silat disertai dengan suara dan teks. Menu animasi ditunjukkan pada gambar 9.

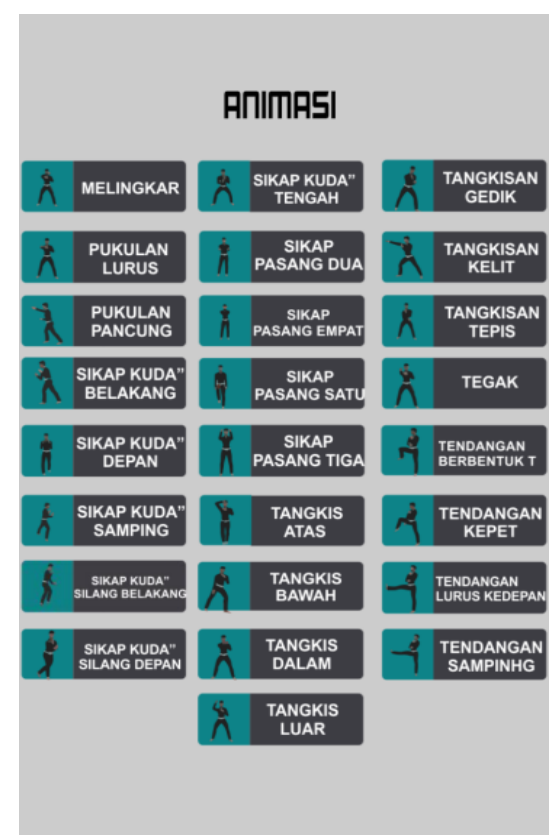

Gambar 9. Isi Menu Animasi

c. Tampilan Isi Menu Evaluasi

Isi dari evaluasi adalah pertanyaan evaluasi yang tujuanya ada fedback yang diperoleh setelah menggunakan aplikasi yang berupa sebuah pertanyaan. Isi menu evaluasi ditunjukkan pada gambar 10 .

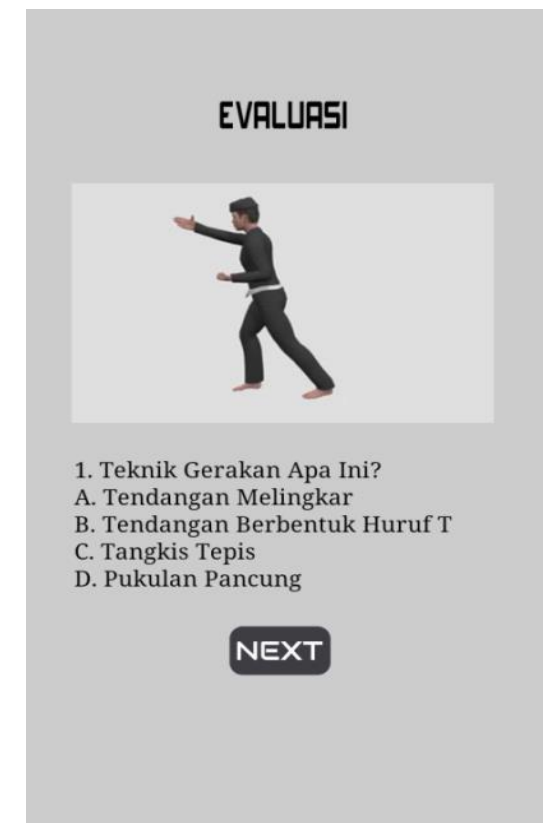

\section{Gambar 10. Isi Menu Evaluasi}

d. Tampilan Isi Menu Galeri

Isi menu galeri adalah pengertian tentang teknik-teknik pencak silat yang disertai dengan gambar dan penjelasan secara merinci. Menu galeri ditunjukkan pada gambar 11 . 


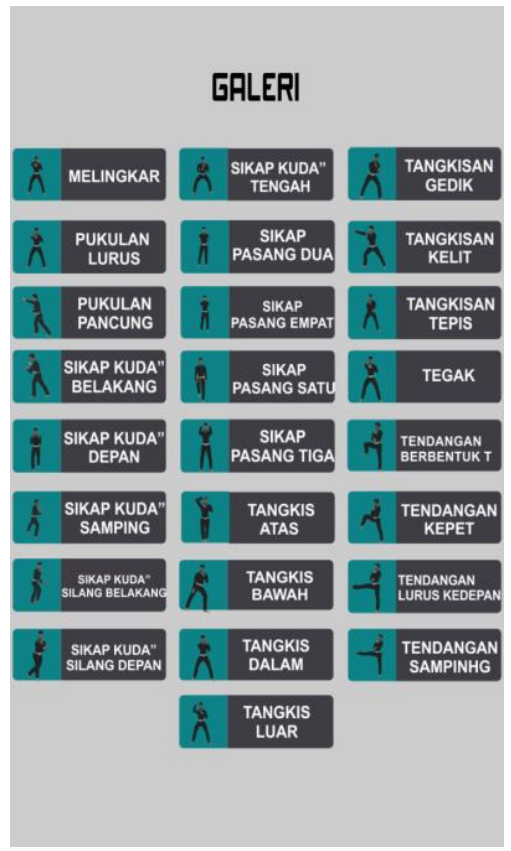

Gambar 11. Isi Menu Galeri

\section{KESIMPULAN}

Dari hasil penelitian dan pembahasan dapat ditarik kesimpulan sebagai berikut :

a. Aplikasi media interaktif animasi 3D teknik-teknik pencak silat berbasis android berjalan sesuai harapan, semua tombol menu berfungsi sesuai fungsinya serta aplikasi berjalan dengan lancar di perangkat dan di harapkan bermanfaat dan untuk pengenalan kesenian pencak silat.

b. Aplikasi media interaktif animasi 3D teknik-teknik pencak silat berbasis android sebagai media pembelajaran yang diharapkan meningkatkan pengetahuan tentang kesenian pencak silat.

c. Aplikasi media interaktif animasi 3D teknik-teknik pencak silat berbasis android telah dibuat (apk) yang dapat dioperasikan disemua perangkat android.

\section{DAFTAR PUSTAKA}

[1] Kriswanto, Erwin S. 2015. Pencak Silat. Pustaka Baru : Yogyakarata.

[2] Safitri, Anna Ayu. 2014. "Rancang Bangun Aplikasi Pembelajaran Aksara Jawa Berbasis Android”. Skripsi. Fakultas Teknik. Program Studi Teknik Informatika. Universitas Muria Kudus.

[3] Arifin, Zaenal et al. 2015. "Membangun Game Petualangan Sejarah Peninggalan Sunan Kudus Berbasis Android. Prosiding SNATIF Ke -2 Tahun 2015 ISBN: 978-602-1180-21-1, Program Studi Teknik Informatika, Fakultas Teknik. Universitas Muria Kudus.

[4] Arifin, Muh Syamsul. 2014. "Sistem Penentuan Bakat Dan Minat Anak Berbasis Mobile Android (Studi Kasus Siswa Kelas 4, 5, Dan 6 Sekolah Dasar)”. Skripsi. Fakultas Teknik. Program Studi Teknik Informatika. Universitas Muria Kudus.

[5] Waskita, Ryo Agung. 2017. "Perancangan Media Interaktif Animasi 3D Teknik-Teknik PencakSilat Berbasis Android”. Skripsi. Fakultas Teknik. Program Studi Teknik Informatika. Universitas Muria Kudus.

[6] Muhydin et al. 2016. Aplikasi Gerakan Dasar (Kihon) Dalam Beladiri Karate Inkai Berbasis Multimedia. Jurnal. Program Studi Ilmu Komputer. Fakultas MIPA. UNPAK.

[7] Yunita Safitri. 2011. Teknik Animasi Dalam Dunia Komputer, Jurnal SAINTIKOM Vol. 10/No. 3. Jurnal. Program Studi Sistem Komputer, STMIK Triguna Dharma.

[8] Wahyu P. 2008. Game Adventure Misteri Kotak Pandora, JurnaL Telematika Vol.1 No. 1. Program Studi Teknik Informatika. STMIK AMIKOM Purwokerto.

[9] Herman M. 2014. Perancangan Media Informasi Penunjang Kesehatan Ibu Hamil Berbasis Multimedia Dengan Metode Pengujian Black Box. Jurnal Paradigmavol XVI no.2 September. Program Studi Manajemen Informatika AMIK BSI Jakarta. 